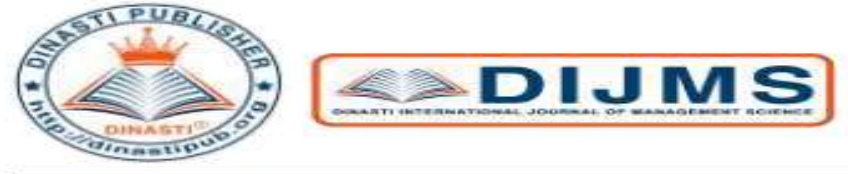

Volume 1, Issue1, September 2019

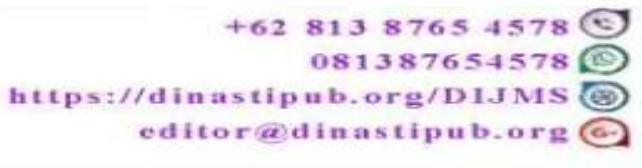

E-ISSN : 2686-522X

P-ISSN : 2686-5211

\title{
THE EFFECT OF PERCEPTION AND PROFIT SHARING ON THE DECISION TO BECOME A CUSTOMER AT BANK BNI SYARIAH MERANGIN REGENCY
}

\author{
Ahmadi \\ Lecturer of Syekh Maulana Qori Islamic College, Bangko, Indonesia
}

\begin{tabular}{l|l|} 
ARTICLE INFORMATION & $\begin{array}{l}\text { Abstract: This study aims to analyze the effect of } \\
\text { Received: 01/09/2019 } \\
\text { Revised: 11/09/2019 } \\
\text { Issued: } 21 / 09 / 2019 \\
\text { of the decision to choose partially, and the perception } \\
\text { and profit sharing of the decision to choose } \\
\text { simultaneously. The design of this study is quantitative } \\
\text { using the survey method. The population of this study is } \\
\text { the customer of BNI Syariah bank in Merangin Regency. } \\
\text { The sample size in this study was determined through } \\
\text { the Slovin formula with e value = 10\%, so that a sample } \\
\text { of 95 people was obtained. This study uses multiple } \\
\text { linear regression analysis techniques. SPSS 21.00 } \\
\text { analysis aid. The results of this study indicate that } \\
\text { perceptions and profit sharing have a positive and } \\
\text { significant effect on the decision to become a customer } \\
\text { at Bank BNI Syariah Merangin Regency. There are still } \\
\text { other factors that influence the decision to choose apart } \\
\text { from the two variables of public perception and profit } \\
\text { sharing. }\end{array}$ \\
Keywords: Perception, Sharing Results and Deciding \\
Choices.
\end{tabular}

\section{INTRODUCTION}

In a country's economy, banks have a very vital role for economic activities, so it can be said that banks are the blood of a country's economy. Therefore the progress of a bank in a country can be used as a measure of the progress of the country concerned. The more developed a country, the greater the role of banks in controlling the country (Kasmir, 2012).

In its operational activities in Indonesia, banks are divided into two namely conventional banks and Islamic banks. The difference between conventional banks and Islamic banks can be seen from the system and its principles. Where the main advantage of conventional banking business is obtained from the difference in deposit interest given to customers with interest on loans or loans channeled. While Sharia Bank in its operation offers profit-sharing benefits from the distribution of funds to customers which consist of various forms of contracts including 
revenue sharing (Mudharabah and Musyarakah), sale and purchase financing (Murabahah, Salam, Istishna) and rental financing (Ijarah, Qord) (Qodriasari, 2014). These differences make Islamic banks increasingly in demand by the public.

The presence of Islamic banks in recent years has provided a diverse perception among the public. Various perceptions, attitudes and behaviors of the community towards sharia banks, among others are caused by the low understanding of the community towards sharia banks, mainly due to the dominance of conventional banks. In addition, the applicable legal and legislative instruments have not fully accommodated the operations of Shari'ah banks, the limited service network of Shari'ah banks and the limited human and syari'ah banking technology (Rahmawaty, 2014).

Perception is one of the things that causes a person to choose Islamic savings. This is because with the perception, then someone will look for information / experience about objects, events, people, and influential factors that can be obtained from the sensing process that causes increased community decisions in choosing sharia savings.

According to Maxwell consumers will decide which products to buy based on their perception of the product related to the ability of the product in meeting their needs. The higher or the better the consumer's perception of the value of a product, the higher the decision to choose a product.

In addition to perceptions, as for other things that make Islamic banks increasingly attractive to the public, namely the existence of a profit sharing system offered by Islamic banks. Revenue sharing is a form of return (acquisition of returns) from an investment contract, from time to time, not certain and not fixed. The size of the recovery depends on the results of the business that actually happened. Thus, it can be said that the profit sharing system is one of the practices of Islamic banking (Antonio, S., 2001).

In the implementation of the profit sharing system in Islamic banks use the profit sharing ratio. Profit sharing ratio is a fairly important factor in determining profit sharing in Islamic banks. Therefore, the profit sharing ratio is an aspect mutually agreed between the two parties conducting the transaction. To determine the profit sharing ratio, it is necessary to consider aspects such as: business data, installment ability, the results of the business carried out, the financing ratio and the distribution of results. Each party that cooperates in a profit sharing system will participate in losses and profits. This case shows fairness in the distribution of income (Muhammad, 2002).

Khasanah, Y and Gunawan's research, A.I (2014) found that the profit sharing system had a significant effect on the decision to become sharia bank customers. These findings occur because the level of profit sharing is so dominant in encouraging someone to open a savings account in an Islamic bank. The management of the bank must compete with profit-sharing levels with competing banks on an ongoing basis, because the customer considers the level of profit sharing in determining whether he will save or not in an Islamic bank.

Based on the background and problems, the objectives to be achieved from this research are:

1) Analyzing the perception of the decision to vote partially.

2) Analyzing the effect of profit sharing on decisions to choose partially.

3) Analyzing the influence of perceptions and profit sharing on decisions simultaneously

\section{LITERATURE REVIEW}




\section{Perception}

Perception is an observation about objects, events or relationships obtained by concluding information and interpreting messages. Perception is giving meaning to sensory stimuli (Rachmat, J., 2008). According to Walgito (2003) perception is a process that is preceded by a sensing process, which is the process of receiving stimuli by individuals through sensory devices or also called sensory processes.

Leavitt (1986) further explains that perception is vision, how a person sees something, whereas in a broad sense is a view or understanding, that is, how a person views or interprets something. It also means that everyone uses their own glasses in looking at his world. Perception can also mean an analysis of how to integrate our application of things around an individual with existing impressions or concepts, and then recognize the object. For example, it can be seen how someone who cannot see, will use his imagination more in forming a perception of an object held, touched, and kissed.

According to Baba, R and Lang, R (2012) as for the dimensions that play a role in forming perceptions, namely: 1) Knowledge of Islamic banks (Knowledge of Islamic banking), this dimension shows knowledge of Islamic banking which includes the reputation of Islamic banks, Islamic banking operational principles and Islamic banks only for Muslim customers; 2) Trust in Islamic banks (Confidence in Islamic banking), this dimension shows a belief in Islamic banks that savings in Islamic banks are safer, investment in Islamic banks is less risky and Islamic banks can compete with conventional banks; and 3) Islamic banking products and services, this dimension shows that Islamic banks provide fast and efficient services, polite and friendly Islamic bank staff and Islamic banks provide a variety of products and services.

\section{Profit sharing}

According to Nasrulloh (2012) profit sharing according to foreign terminology (UK) is known as profit sharing, profit is profit. In the economic dictionary, it is defined as profit sharing. In terms of profit is the difference that arises when the total revenue of a company is greater than the total cost.

Profit sharing according to the Sharia Banking Development Team of the Indonesian Bankers Institute is an agreement on the amount of each profit sharing portion to be obtained by the owner of the fund (sahibul maal) and fund manager (mudarib) as stated in the agreement / agreement that was signed at the beginning before the cooperation was carried out . profit sharing system is a special feature that distinguishes Islamic banking from conventional banking which uses the interest system in terms of profit sharing (Ikatan Bank Indonesia, 2014).

As according to Muhammad (2005), in terms of profit sharing is the distribution of some parts of profits to employees of a company. These forms of distribution can be in the form of the distribution of final profits, performance bonuses, and others. Thus, profit sharing is a system that includes procedures for the distribution of business results between the fund owner and fund manager. This division of business can occur between the bank and the depositor of funds, as well as between the bank and the customer receiving the funds. Forms of products that use this principle are mudaraba and musharaka. Furthermore, the mudharabah principle can be used as a basis for both funding products (savings and deposits) and financing, while musharaka is more for financing.

According to Hasan, MA (2003) as for the indicators used to measure profit sharing, namely: 1) Profitable, namely the profit sharing system used by the bank is an acceptable profit sharing system because it is beneficial both for the Bank and customers for using the system sharia according to the quran; 2) Does not burden the customer, that is, the payment does not 
burden the customer; and 3) There is transparency, namely the existence of transparency between the Bank and customers.

\section{Decision to Choose}

Decisions are the result of resolution in a problem that must be dealt with firmly. In large dictionaries science decision making is defined as the selection of decisions or policies based on certain criteria. This process includes two or more alternatives because if there was only one alternative there would be no decisions to be made (Dagun, 2006). According to Reason (1990) decision making can be considered as a result or output of mental or cognitive processes that lead to the selection of an action path between several alternatives.

Terry in Syamsi, I (2000) argues that decision making is an election based on certain criteria or two or more possible alternatives. According to Kotler and Keller (2012) decision making is the stage in a person's decision making process where the consumer really chooses Decision making is an activity of individuals who are directly involved in obtaining and using the goods offered.

Furthermore Harold and Cyril O'Donnell in Kotler and Keller (2012) said that decision making is the choice between alternatives regarding a way of acting that is the core of planning, a plan cannot be said to be non-existent if there is no decision, a reliable source, instructions or reputation that has been made. Siagian defines keputusa is a systematic approach to a problem, gathering facts and data, mature research on alternatives and actions.

According to Kotler (2010) the decision making process consists of 5 stages, marketers must try to fully understand the customer's decision making process starting from the customer's experience in learning, choosing, using, and proposing products. Kotler further explained that consumers generally go through five stages in the decision making process, namely:

1) Introduction to the problem. This process starts when the customer recognizes a problem or need. For this reason, marketers need to identify conditions that trigger certain needs, by gathering information from a number of consumers, thus marketers can develop marketing strategies that can trigger consumer interest.

2) Information search. Consumers who are stimulated by their needs will be encouraged to find more information. The main concern of marketers is the main sources of information that become consumers' reference and the relative influence of each source on subsequent purchasing decisions.

3) Evaluate alternatives. There is no single, simple evaluation process used by all consumers or by one consumer in all purchasing situations. Evaluation is based on beliefs and attitudes obtained from acting and learning.

4) Buying decision. Consumers can take the decision not to formally evaluate each brand, but the intervening factors can influence the final decision.

5) Post-purchase behavior. After purchase, consumers may experience discrepancies due to noticing certain annoying features or hearing pleasant things about other brands, and will always be alert to information that supports their decision. For this reason, marketers must monitor post-purchase satisfaction, post-purchase actions, and use of post-purchase products.

\section{Conceptual Framework}

Based on the background, the study of theory and research that is relevant then the conceptual framework of this research is like Figure 1 below. 


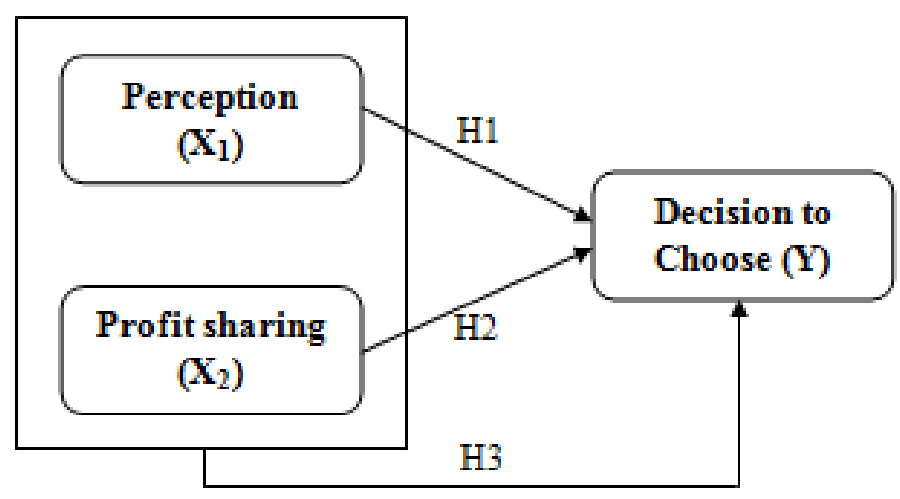

Figure 1. Conceptual Framework

\section{Research Hypothesis}

Based on the research objectives, the research hypothesis is:

1) Perception influences the decision to vote partially.

2) The profit sharing ratio influences the decision to vote partially.

3) Personnel and profit sharing ratio influence the decision to choose simultaneously.

\section{RESEARCH METHODS}

The unit of analysis of this research is the customer of Bank BNI Syariah at BNI Syariah Bangko Regency. The sample size in this study was determined through the Slovin formula with e value $=10 \%$, so that a sample of 95 people was obtained. Quantitative analysis method, with an analysis tool with multiple linear regression, with the equation $\mathrm{Y}=\mathrm{a}+\mathrm{b} 1 . \mathrm{X} 1+\mathrm{b} 2 . \mathrm{X} 2+\mathrm{e}=$, where $\mathrm{Y}$ is the decision variable choose, b1 and b2 perception variable coefficients (X1) and profit sharing (X2). Data analysis tools for SPSS application programs version 21.0.

After being analyzed by multiple linear regression, followed by a test of determination analysis (RSquare), partial hypothesis testing ( $\mathrm{t}$ test) and simultaneous ( $\mathrm{F}$ test) with a 5 percent error tolerance level. But before the process carried out the Multiple Linear Regression equation was first tested the research instrument (questionnaire) with validity and reliability tests and classic assumptions through normality, multicollinearity, and homogeneity tests.

\section{FINDINGS AND DISCUSSION}

\section{Finding}

\section{Description of Research Variables}

Descriptive statistics used are mean (mean) values, values that often appear in the respondent's answer (mode), middle values (median), standard deviations (standard deviations) and sample variance. The results of descriptive statistics in the study using the SPSS 21.0 tool as follows:

Table 1. Descriptive Statistics of Research Variables

\begin{tabular}{lrrrr}
\hline \multicolumn{5}{c}{ Statistics } \\
\\
\hline \multirow{2}{*}{$\mathrm{N}$} & X1_Perception & X2_Profit_Sharing & Y_Decision_to_Choose \\
\cline { 2 - 5 } & Valid & 95 & 95 & 95 \\
\hline Mean & Missing & 0 & 0 & 0 \\
\hline Std. Error of Mean & 3,877 & 4,015 & 3,634 \\
\hline
\end{tabular}




\begin{tabular}{lrrr}
\hline Median & 4,000 & 4,200 & 3,750 \\
\hline Mode & 4,500 & 4,4 & 4,00 \\
\hline Std. Deviation &, 552430 &, 6960 &, 65111 \\
\hline Variance &, 305 &, 484 &, 424 \\
\hline Range & 2,250 & 2,6 & 3,00 \\
\hline Minimum & 2,750 & 2,4 & 2,00 \\
\hline Maximum & 5,000 & 5,0 & 5,00 \\
\hline Sum & 368,375 & 381,4 & 345,25 \\
\hline \multicolumn{2}{r}{ Source: Output SPSS 21.0} & &
\end{tabular}

Before assessing the criteria of the research variable, a score assessment criteria will be made first. With the highest number of scores is 5 , and the lowest number of scores is 1 . The classification of respondents' answers to the research variables can be described in the weighting stages of the score with a score range of $5-1 / 5=0.8$, as follows:

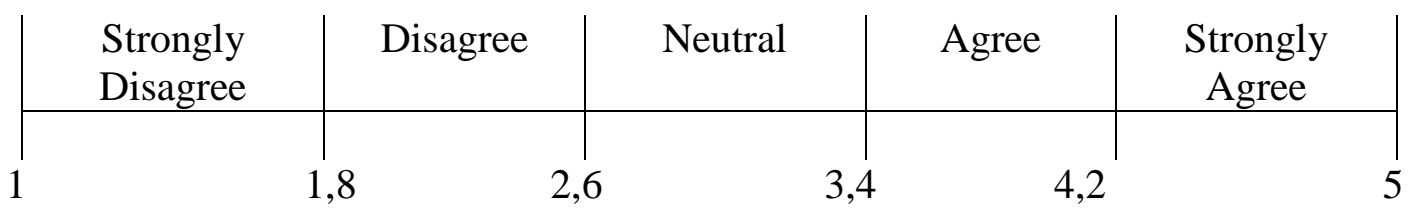

a. Description of Perception Variable (X1)

Descriptive results for the perception variables as shown in Table 1 above obtained an average value of 3.877 including in the range of 2.6 - 3.4 are in the Agree criteria. Which explains that customers have a good perception of Islamic banks.

\section{b. Description of Variable Sharing (X2)}

Descriptive results for the profit-sharing variables as shown in Table 1 above obtained an average value of 4.015 including in the range of 2.6 - 3.4 are in the Agree criteria. Which explains that the customer agrees if the revenue sharing is one of the reasons for customers interested in choosing an Islamic bank.

\section{c. Description of the Decision Choosing Variable (Y)}

The descriptive results of the decision-making variables as shown in Table 1 above obtained an average value of 3.634 including in the range of $3.4-4.2$ being in the Agree criteria. Which explains the customer agrees that in making the decision to choose to save at Islamic Banks because this product is the first choice, the best choice, according to needs, and the benefits.

The results of the interpretation of the summary model, Coefficients, and Anova from the quantitative analysis of Multiple Linear Regression output as below.

A good model of multiple linear regression equations that can be passed on to the next analysis is one that meets the requirements of the classical assumptions, among other things, all data are normally distributed, the model must be free from heterocedasticity.

From the results of tests carried out using SPSS 21.0 as a tool in this study the results show that the data in this study are normally distributed, this is evidenced by the results of the significance value (Asymp. Sig. 2-tailed) greater than 0.05 , i.e. $(0.373>0.05)$ so that it can be concluded that the data in this study are normally distributed.

Then from the results of the multicollinearity test it is known that the results of the calculation of Tolerance values show that there are no independent variables that have a Tolerance value of less than 0.10 , which means there is no correlation between the independent 
variables. Besides that, the calculation of the Variance Inflation Factor (VIF) value also shows the same thing that there is not one independent variable that has a VIF value of more than 10. So it can be concluded that there is no multicollinearity between the Independent variables in the regression model.

Furthermore, from the results of heteroscedasticity test, it is known that scatterplots show that the points spread randomly and spread both above and below the number 0 on the Y axis. enter independent variables.

Based on these tests it has been proven that the equation model proposed in this study has met the requirements of classical assumptions so that the equation model in this study is considered good. Multiple linear regression analysis is used to test the hypothesis of partial and simultaneous influence of independent variables on the dependent variable. Based on multiple linear regression coefficients with the SPSS 21.0 program, the results shown in Table 2 below:

Table 2. Coefficients

Coefficients $^{\mathrm{a}}$

\begin{tabular}{|c|c|c|c|c|c|c|}
\hline \multirow[t]{2}{*}{ Model } & & \multicolumn{2}{|c|}{$\begin{array}{c}\text { Unstandardized } \\
\text { Coefficients }\end{array}$} & \multirow{2}{*}{$\begin{array}{c}\begin{array}{c}\text { Standardized } \\
\text { Coefficients }\end{array} \\
\text { Beta }\end{array}$} & \multirow[t]{2}{*}{$\mathrm{t}$} & \multirow[t]{2}{*}{ Sig. } \\
\hline & & $\mathrm{B}$ & Std. Error & & & \\
\hline \multirow{3}{*}{1} & (Constant) & 1,940 & 1,417 & & 1,369 & , 174 \\
\hline & X1_Perception &, 173 &, 056 & ,294 & 3,112 &, 002 \\
\hline & X2_Profit_Sharing & ,360 &, 071 & ,481 & 5,095 &, 000 \\
\hline
\end{tabular}

a. Dependent Variable: Y_Decision_to_Choose

Source: Output SPSS under 21.00

From Table 2 above we get the results of multiple linear regression equations: $\mathrm{Y}=\alpha+$ $\mathrm{b}_{1} \cdot \mathrm{X}_{1}+\mathrm{b}_{.2} \mathrm{X}_{2}+\mathrm{e}=1,940+0,173 \cdot \mathrm{X}_{1}+0,360 \cdot \mathrm{X}_{2}+\mathrm{e}$. Description: $\mathrm{Y}=$ Decision to choose; $\mathrm{X}_{1}=$ perception, and $\mathrm{X} 2$ = profit sharing. From this equation can be interpreted: 1 ) perceived variables and profit sharing have a coefficient direction that is positive on the decision to vote; 2) a constant value of 1,940 indicates that the perception and profit share are constant or constant, then the value of the decision to vote is $1.940 ; 3)$ The regression coefficient value of the perception variable towards the decision decision variable is 0.173 meaning that if the perception value of the Islamic bank is better and increased by one unit, it will increase the value of the decision to vote by 0.173 , or in other words if the perception can be improved by 100 scales, then it will be followed by an increase in the decision to vote by 100 scales; 4) The value of the regression coefficient of the profit-sharing variable to the decision-making variable is 0.360 , meaning that if the revenue share is increased by one unit, it will increase the value of the decision-making value by 0.360 , or in other words if the profit sharing provided can be improved by 100 scales, then this will also be followed by an increase in the decision of 100 scales.

\section{Determination Analysis Results $\left(\mathbf{R}^{2}\right)$.}

To see the total effect of the perception variable $\left(\mathrm{X}_{1}\right)$ and profit sharing $\left(\mathrm{X}_{2}\right)$ on the decision to choose $(\mathrm{Y})$ can be seen from the coefficient of determination $\mathrm{R}^{2}$ as shown in Table 3 below: 


\section{Tabel 3. Model Summary}

Model Summary

\begin{tabular}{lcccr}
\hline Model & $\mathrm{R}$ & $\mathrm{R}$ Square & Adjusted R Square & Std. Error of the Estimate \\
\hline 1 &, $701^{\mathrm{a}}$ &, 492 &, 481 & 1,8763 \\
\hline $\begin{array}{l}\text { a. Predictors: (Constant), X2_Profit_Sharing, X1_Perception } \\
\text { Source: } \text { Output SPSS under 21.00 }\end{array}$
\end{tabular}

$\mathrm{R}$ value of 0.701 shows a double correlation (perception and profit sharing) with the decision to choose. Taking into account the variation in the value of $\mathrm{R}$ Square of 0.492 which shows the magnitude of the role or contribution of the perception variable and profit sharing is able to explain the decision-making variable of 49.2 percent and the remaining 50.8 percent is influenced by other factors not revealed in this model.

\section{Results of Partial Influence Test (t Test) and Simultaneous Effect (F Test)}

Hypothesis testing aims to explain the characteristics of certain relationships or differences between groups or the independence of two or more factors in a situation, (Ali, H., and Limakrisna, N., 2013). Testing the partial effect aims to test whether each independent variable has a significant effect on the dependent variable partially with $\alpha=0.05$ and also the acceptance or rejection of the hypothesis. Partial test ( $t$ test) to answer hypotheses one and two of this study.

\begin{tabular}{|c|c|c|c|}
\hline \multicolumn{4}{|c|}{ Tabel 4. $t$ Test Results (Partial) } \\
\hline Model & & $\mathrm{t}$ & Sig. \\
\hline \multirow{3}{*}{1} & (Constant) & 1,369 &, 174 \\
\hline & X1_Perception & 3,112 &, 002 \\
\hline & X2_Profit_Sharing & 5,095 &, 000 \\
\hline
\end{tabular}

1) The Effect of Perception on Decisions to Vote

From Table 4 above, the $t_{\text {count }}$ of the perception variable is obtained at 3.112, with a significance level of 0.000 , because the number of significance levels is more $<0.05(0.002$ $<0.05$ ), it can be concluded that the perception influences the decision to choose. Thus the first hypothesis is proven and accepted.

The results of this study show the same results with research conducted by Ilmawan, N.F (2017) which suggests that public perception positively and significantly influences the decision of the selection of Islamic banks. According to Maxwell consumers will decide which products to buy based on their perception of the product related to the ability of the product in meeting their needs. The higher or better the consumer's perception of the value of a product, then the interest in buying a product is also higher.

2) The Effect of Profit Sharing on Decision to Choose 
Furthermore, in Table 4 above, the $\mathrm{t}_{\text {count }}$ number of the decision-making variable is obtained at 5.095, with a significance level of 0.000 , because the significance level is much more $<0.05(0.000<0.05)$, so it can be concluded that the results share influence on the decision to vote. Thus the second hypothesis is proven and acceptable.

The results of this study are in line with the research conducted by Khasanah, $\mathrm{Y}$ and Gunawan, A.I (2014) found that the profit sharing system significantly influences the decision to become sharia bank customers. These findings occur because the level of profit sharing is so dominant in encouraging someone to open a savings account in an Islamic bank. The management of the bank must compete with profit-sharing levels with competing banks on an ongoing basis, because the customer considers the level of profit sharing in determining whether he will save or not in an Islamic bank.

To answer the third hypothesis that perception and profit sharing affect the decision to choose simultaneously can be seen from Table 5 below.

Table 5. Anova

\begin{tabular}{|c|c|c|c|c|c|c|}
\hline \multicolumn{7}{|c|}{ ANOVA $^{a}$} \\
\hline Model & & Sum of Squares & Df & Mean Square & $\mathrm{F}$ & Sig. \\
\hline \multirow{3}{*}{1} & Regression & 313,738 & 2 & 156,869 & 44,559 &, $000^{\mathrm{b}}$ \\
\hline & Residual & 323,883 & 92 & 3,520 & & \\
\hline & Total & 637,621 & 94 & & & \\
\hline
\end{tabular}

a. Dependent Variable: Y_Decision_to_Choose

b. Predictors: (Constant), X2_Profit_Sharing, X1_Perception

Source: Output SPSS under 21.00

From Table 5 above (ANOVA table) a Fcount of 44.559 is obtained, and a significant value of 0.000 is less than $0.05(0.000<0.05)$. Then the null hypothesis $\left(\mathrm{H}_{0}\right)$ is rejected and the alternative hypothesis $\left(\mathrm{H}_{1}\right)$ is accepted, meaning that there is a significant effect of perception and profit sharing on the decision to choose together (simultaneous). Thus the third hypothesis is proven and acceptable.

Perception is one of the things that causes a person to have an interest. This is because with the perception, then someone will look for information / experience about objects, events, people, and influential factors that can be obtained from the sensing process that causes an interest. While the profit sharing ratio is a fairly important factor in determining profit sharing in the Islamic bank. Therefore, the profit sharing ratio is an aspect mutually agreed between the two parties conducting the transaction

\section{CONCLUSION AND SUGGESTION}

\section{Conclusion}

Based on the results and discussion, the conclusions of this study are:

1) Partial perception has an influence on the customer's decision in choosing an Islamic bank. This shows that if the customer has a good perception of knowledge, trust, and products and services. Then it will affect the customer's decision in choosing BNI Syariah bank. 
2) Revenue sharing has an influence on the customer's decision in choosing BNI Syariah bank. This shows that if the profit sharing system implemented by BNI Syariah can benefit customers, not burdensome for customers, as well as transparency by the bank, then this will also be followed by the increasing decision in choosing BNI Syariah banks.

3) Simultaneous perception and profit sharing affect the customer's decision in choosing BNI Syariah bank. This explains that, if the customer has a good perception of the BNI Syariah bank, and is supported by the existence of a profit sharing system, it will further enhance the customer's decision in choosing BNI Syariah bank.

\section{Suggestion}

Based on data analysis, the process of statistical calculations, testing of empirical research models and discussion of the results of studies conducted, several suggestions are given as follows:

1) In the future, it is expected that BNI Syariah Bangko management will further enhance the socialization of the products offered to the public so that the public is more aware of the differences between Islamic and conventional banks. This is very important, because the better the public's knowledge of Islamic bank products, the better the public's perception of Islamic banks. In addition, companies must also be more observant in looking at current customer needs so that they can improve product quality and service.

2) Future management of BNI Syariah Bangko is expected to be able to manage mudharabah funds to the maximum so that profit sharing and profits received by customers are increasing in accordance with agreed ratios, so that customers are encouraged to use mudharabah savings banking services.

3) The need for a more in-depth study of the perceptions and profit sharing ratio of customers' decisions in choosing a Sharia Bank in order to find out relevant factors, which are more dominant in influencing a customer's decision in choosing a Sharia Bank.

\section{REFERENCE}

Ali, H., \& Limakrisna, N. (2013). Research Methodology, Practical Guide to Business Problem Solving Preparation of Theses and Dissertation, ISBN: 978-602-280-044-6, Deepublish Yogyakarta, Indonesia.

Antonio, M.S. (2001). Bank Syariah dari Teori ke Praktik. Jakarta: Gema Insani Press dan Tazkia Cendikia.

Baba, R and Lang, R. (2012). Perceptions of Non Muslim Towards Islamic Banking. Banker's Journal Malaysia, 10, No. 138.

Dagun, M.S. (2006). Kamus Besar Ilmu Pengetahuan. Jakarta: Lembaga Pengkajian Kebudayaan Nusantara (LPKN)

Hasan, M.A. (2003). Berbagai Macam Transaksi dalam Islam (Fiqih Muamalat). Jakarta: RajaGrafindo Persada.

Ikatan Bankir Indonesia. (2014). Mengelola Bank Syariah. Jakarta: PT. Gramedia Pustaka Utama.

Ilmawan, N.F. (2017). Pengaruh Persepsi dan Sikap Usaha Terhadap Pemilihan Bank Syariah Setelah Fatwa Majelis Ulama Indonesia di Kauman Surakarta. Tesis IAIN Surakarta.

Kasmir. (2008). Pemasaran Bank, Edisi Revisi. Jakarta: Prenade Media Group. 
Khasanah, Y dan Gunawan, A.I. (2014). Pengaruh Sistem Bagi Hasil Terhadap Keputusan Menjadi Nasabah Bank Syariah di Kota Cirebon (Penelitian Survei Terhadap Nasabah Bank Syariah di Kota Cirebon). Jurnal Edumic, Volume 2, No. 1.

Kotler, P. (2010). Manajamen Pemasaran, Jilid 1 dan 2. Jakarta: PT. Indeks Kelompok Gramedia

Kotler, P. dan Keller, K.L. (2012). Manajemen Pemasaran. Jilid 1 dan 2. Jakarta: PT Indeks.

Leavit, J.R. (1986). Psikologi Manajemen: Sebuah Pengantar bagi Individu dan Kelompok di dalam. (terjemahan: Zakarsi, M. Ed. 4). Jakarta: Erlangga.

Muhammad. (2002). Manajemen Bank Syari'ah. Yogyakarta: UPP AMP YKPN.

Muhamad. (2005). Sistem dan Prosedur Operasional Bank Syari'ah. Yogyakarta: UII Press.

Nasrulloh, A.A. (2012). Pengaruh Bagi Hasil Terhadap Dana Pihak ketiga Perbankan Syariah di Indonesia. Jurnal Akutansi Vol 7, Nomor 1.

Qodriasari, I.L. (2014) Analisis Pengaruh Pendapatan Pembiayaan Mudharabah, Musyarakah, Murabahah, Dan Sewa Ijarah Terhadap Profitabilitas Bank Umum Syariah Di Indonesia Periode Tahun 2011-2013. Skripsi thesis, Universitas Muhammadiyah Surakarta.

Rakhmat, J. (2008). Psikologi Komunikasi. Bandung: PT. Remaja Rosdakarya Offset.

Rahmawaty, A. (2014). Pengaruh Persepsi Tentang Bank Syariah Terhadap Minat Menggunakan Produk di BNI Syari'ah Semarang. ADDIN, Vol. 8, No. 1.

Reason, J. (1990). Human Eror. Ashgate. ISBN 1-84014-104-2, 1990.

Syamsi, I. (2000). Pengambilan Keputusan dan Sistem Informasi. Jakarta: Bumi Aksara.

Walgito, B. (2004). Pengantar Psikologi Umum. Yogyakarta: Andi Offset 